\title{
腔扁平上皮癌の被膜外頸部リンパ節転移と臨床病理組織像との関連性
}

\author{
黒川英雄・山下善弘・三浦恵子・村田朋之 \\ 武田忍・田部大·岡本勝 * \\ 福山宏*. 寺坂修治**
}

\section{Relation between extracapsular cervical lymph node metastasis and clinicopathological features in oral squamous cell carcinoma}

\author{
Hideo Kurokawa Yoshihiro Yamashita $\cdot$ Keiko Miura $\cdot$ Tomoyuki Murata \\ Shinobu Takeda $\cdot$ Futoshi Tabe $\cdot$ Masaru Okamoto* \\ Hiroshi Fukuyama * Shuji Terasaka ${ }^{* *}$
}

\begin{abstract}
The relation between extracapsular cervical lymph node extension (ECLNE) and clinicopathological prognostic factors was investigated retrospectively in 19 patients with oral squamous cell carcinoma who had undergone radical neck dissection from 1981 through 1996 at our department.

The results were as follows:

1. Forty-eight patients (52.2\%), 102 lymph nodes (8.9\%), had cervical lymph node metastasis; in 19 patients (39.6\%), 29 lymph nodes (28.4\%) were associated with ECLNE.

2 . The incidence of ECLNE was high in patients with primary lesions of the maxillary and mandibular gingivae.

3 . As for the distribution of involved lymph nodes, the majority were found in Level 2 (upper deep cervical lymph nodes).

4. The averege dimensions of ECLNE were $14.4 \pm 6.5 \mathrm{~mm}$ (shortest diameter) and $20.8 \pm 6.7 \mathrm{~mm}$ (longest diameter).

5. There was a relation between ECLNE and the pathological features (mode of invasion and histological malignancy) of primary lesions.

6 . These results suggest that adjuvant therapy, such as postoperative chemotherapy or radiotherapy (or both), and prophylactic neck dissection with primary tumor exicision might be beneficial in patients with grades $4 \mathrm{C}, 4 \mathrm{D}$, and high grade malignancy.
\end{abstract}

Key words: oral squamous cell carcinoma (口腔扁平上皮癌), extracapuslar cervical lymph node extension (被膜外頸部リンパ節転移), mode of invasion (浸潤様式), histological grading of malignancy (組織学的悪性度)

緒

\section{言}

口腔扁平上皮癌の頸部リンパ節転移, とくに被膜外頸部
リンパ節転移 (以下, 被膜外浸潤) は治療成績を左右する 重要な因子とされている1，2).わたくしたちは，これまで に口腔扁平上皮癌における頸部リンパ節転移ならびに後
九州歯科大学口腔外科学第 2 講座

(主任代行 : 福田仁一教授)

*九州歯科大学口腔病理学講座

(主任 : 福山 宏教授)

**大分赤十字病院歯科口腔外科

(科長 : 山本益四郎部長)

Second Department of Oral and Maxillofacial
Surgery, Kyushu Dental College (Acting chief:

Prof. Jinichi Fukuda)

*Department of Oral Pathology, Kyushu Dental

College (Chief: Prof. Hiroshi Fukuyama)

** Department of Dentistry and Oral Surgery, Oita

Red Cross Hospital (Chief: Ekishirou Yamamoto)

受付日: 平成11年 9 月 16 日 
発頸部リンパ節転移の臨床病理組織学的検討を行ってき た ${ }^{3,4}$ ) が, 今回は頸部リンパ節転移の被膜外浸潤の様相を 把握するために, 原発巣と転移リンパ節との関連性を臨床 病理組織学的に検討したので, その成績を報告する.

\section{対象症例および方法}

1981年より1996年までの17年間に, 当科を受診した口腔 扁平上皮癌一次症例 255 例のうち, 頸部リンパ節転移の被 膜外浸潤を認めた19例, 29リンパ節を対象として, 頸部リ ンパ節転移の被膜外浸潤状況と原発巣における各種要因と の関連性について検討を加えた. 対象症例は40歳から83歳 までの男性 12 例, 女性 7 例である. 発現部位は上顎歯肉 9 例, 下顎歯肉 6 例, 舌 2 例, 口底 1 例, 煩粘膜 1 例である. また，原発巣の進展度および臨床病期分類はUICC 分 類 $(1987)^{5)}$ にて分類し, T $1 \cdot 3$ 例, T $2 \cdot 11$ 例, T $3 \cdot 3$ 例, $\mathrm{T} 4 \cdot 2$ 例, Stage I $\cdot 1$ 例, Stage II $\cdot 4$ 例, Stage III $\cdot 9$ 例, StageIV・5 例である（表 1 ）。なお，原発巣に対する治療 法は全例とも外科療法を主体とし, 術前化学療法あるいは 放射線療法との組み合わせを行っている.また, 頸部廓清 の時期について, 転移が疑われた場合は原発巣と同時に行っ ているが, 原則的に積極的な予防的頸部廓清は行わない方 針としている.

被膜外浸潤の評価は, 転移リンパ節の連続切片, $\mathrm{H} \cdot \mathrm{E}$ 染 色標本を作成し, 転移腫瘍細胞の浸潤によってリンパ節被 膜の連続性が失われ，転移腫瘍細胞が周囲組織へ浸潤して いるものとした ${ }^{6 \sim 8)}$. 被膜外浸潤様式は Toker $\left.{ }^{9}\right)$ の分類 を，また，原発巣の浸潤様式はYamamoto ら ${ }^{10)}$ の基準を， 組織学的悪性度は治療前の生検材料をもとにAnneroth ら11) の基準にそれぞれ従った.なお，統計学的には， $\mathrm{T}$ 検 定および $\chi^{2}$ 検定を行い, 危険率 $5 \%$ 以下を有意差とした.

表 1 対象症例

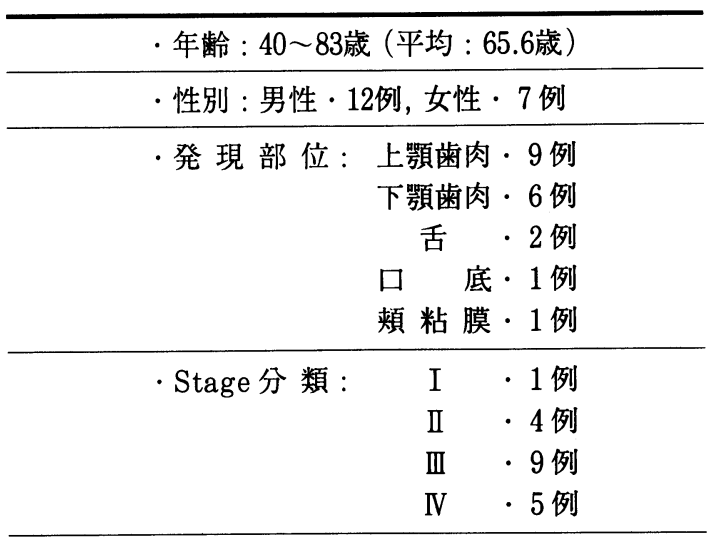

結

果

\section{1 . 被膜外浸潤の頻度}

調査期間中に全頸部郭清手術を行った 92 例, 1149 リンパ 節のうち, 組織学的に頸部リンパ節転移が確認されたもの は48例 $(52.2 \%), 102$ リンハ節 $(8.9 \%)$ であった.このうち, 頸部リンパ節の被膜外浸潤を認めたものは19例（郭清症例 の $20.7 \%$, 転移症例の $39.6 \%$ ), 29 リンパ節（総リンパ節の $2.5 \%$, 転移リンパ節の $28.4 \%)$ であった.

\section{2. 被膜外浸潤と原発巣の臨床像}

被膜外浸潤症例を原発部位別にみると，上顎歯肉が52.9 \% ( $9 / 17$ 例) と最も多く, ついで下顎歯肉が50.0\%（6／ 12例), 煩粘膜 $33.3 \%$ ( $1 / 3$ 例 ), 口底 $33.3 \%$ ( $1 / 3$ 例 $)$, 舌15.4\%（2/13例）であった

$\mathrm{T}$ 分類別では，T 1 が $33.3 \%$ （ $3 / 9$ 例 )， T 2 が $42.3 \%$ (11/26例), T 3 が37.5\% ( $3 / 8$ 例), T 4 が40.0\%（ $2 / 5$ 例）と, 特別な傾向はみられなかった. また, Stage 分類で は, Stage I が20.0\%（1／5 例), Stage II が36.4\%（4／ 11例), Stage III が40.9\%（ $9 / 22$ 例 $),$ Stage IV が50.0\%（ 5 /10）となり, 病期の進行とともに被膜外浸潤が増加して いた。

被膜外浸潤のみられた転移リンパ節は顎下リンパ節, 上 内深頸リンパ節, 中内深頸リンパ節にみられ，とくにレベ ル 2 に集中していた（図1）.

被膜外浸潤を認めた転移りンパ節の大きさは短径が 4.5

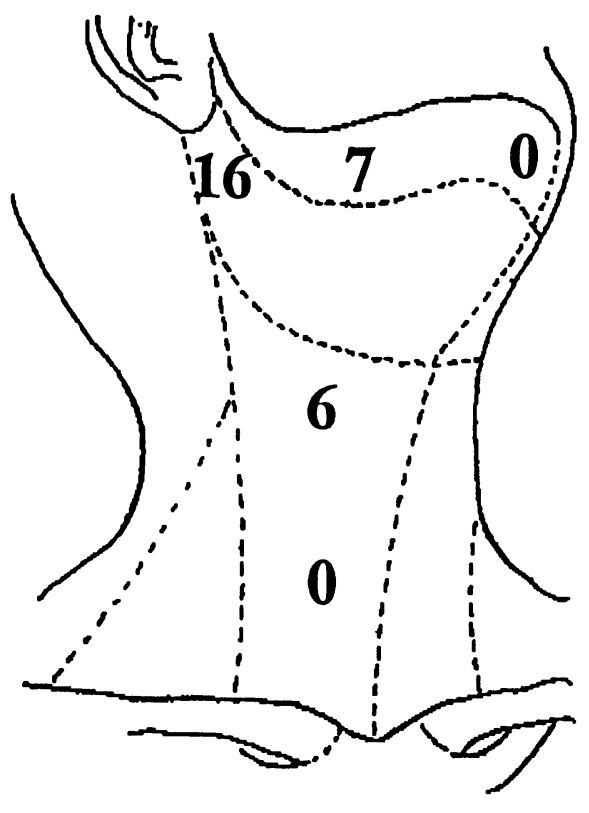

図 1 被膜外リンパ節転移の部位 
$\mathrm{mm}$ から $33 \mathrm{~mm}$ の平均 $14.0 \pm 6.5 \mathrm{~mm}$ で, 長径が $8 \mathrm{~mm}$ か ら $40 \mathrm{~mm}$ の平均 $20.8 \pm 6.7 \mathrm{~mm}$ であった（図 2 ).

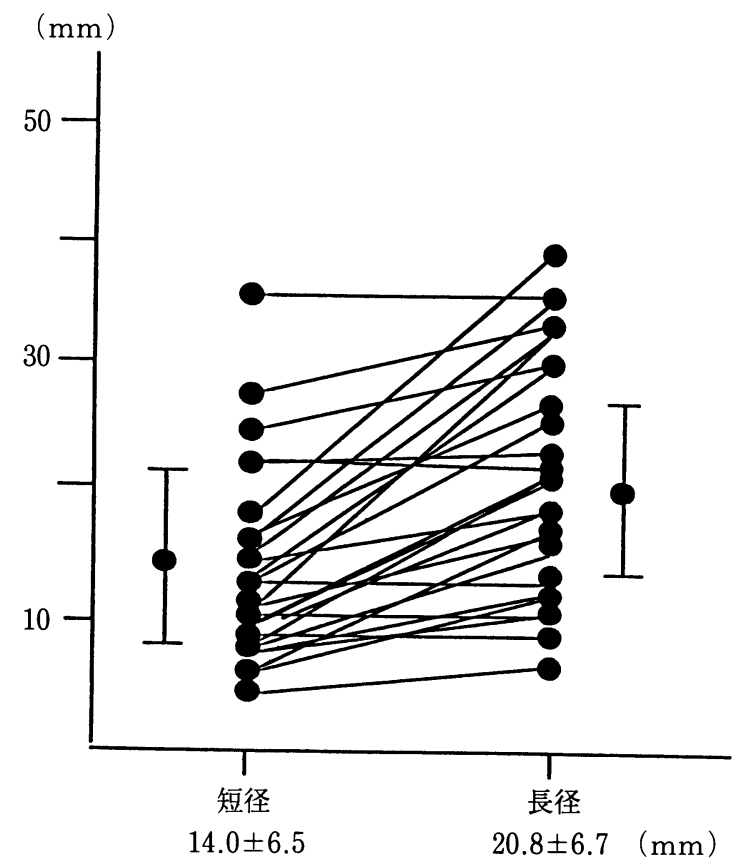

図 2 被膜外リンパ節転移の大きさ

\section{3 . 被膜外浸潤症例の予後}

病理組織学的に頸部リンパ節転移を認めた症例 (48例), 認めなかった症例（44例）および被膜外浸潤症例（19例） の予後を Kaplan-Meier 法 ${ }^{12)} に よ る 5$ 年累積生存率で検討 した。

頸部リンパ節に転移を認めなかった症例の 5 年累積生存 率が75.6\%であったのに対し，転移を認めた症例は $42.0 \%$, 被膜外浸潤を認めた症例は $27.8 \%$ となり，頸部リンパ節転 移の被膜外浸潤が予後に大きく関与することが示唆された (図 3 ).

\section{4. 被膜外浸潤と原発巣の病理組織像}

1 ) 組織学的悪性度との関連

原発巣の組織学的悪性度によるリンパ節転移の被膜外浸 潤率をみると, 全症例 255 例のうち低悪性型が $3.4 \%$, 中等 度悪性型が7.9\%, 高悪性型が15.5\%となり, 悪性度が高く なるにつれて, 被膜外浸潤率が上昇していた。 また, 被膜外 浸潤のみられた19例のうち, 高悪性型が有意に高い頻度を 占めていた，さらに, 組織学的に転移陽性の102リンパ節で も，高悪性型の頻度が有意に高くなっていた（図 4)。

2 ) 浸潤様式との関連

原発巣の浸潤様式とリンパ節転移との関連をみると, 4 C，4 D 型が最も転移頻度が高く 2 型や 3 型と有意差が 認められた。 そのうち被膜外浸潤症例では，4C，4D型が $55.6 \%$ と高率を示し，3 型との有意差が認められた（表 2 ).

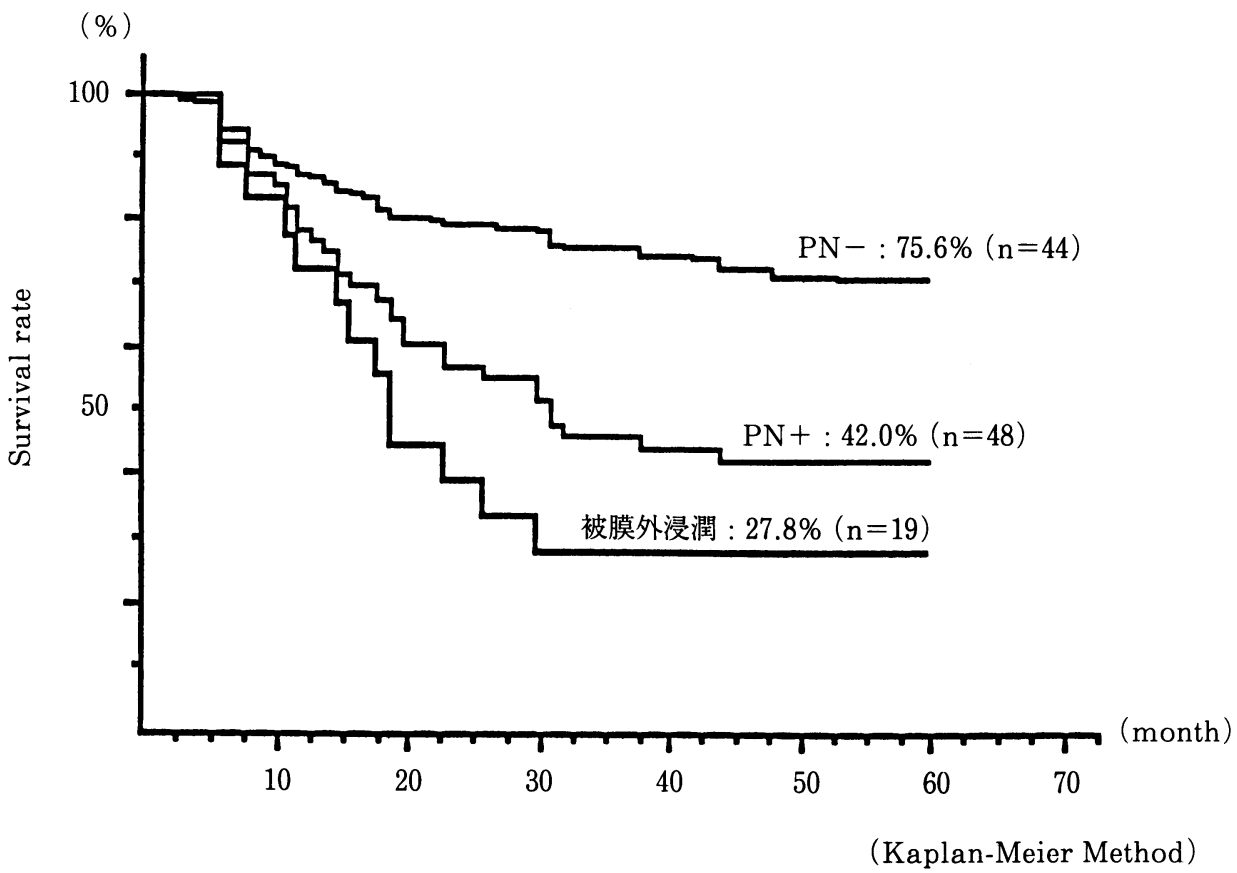

図 3 口腔扁平上皮癌の生存率 

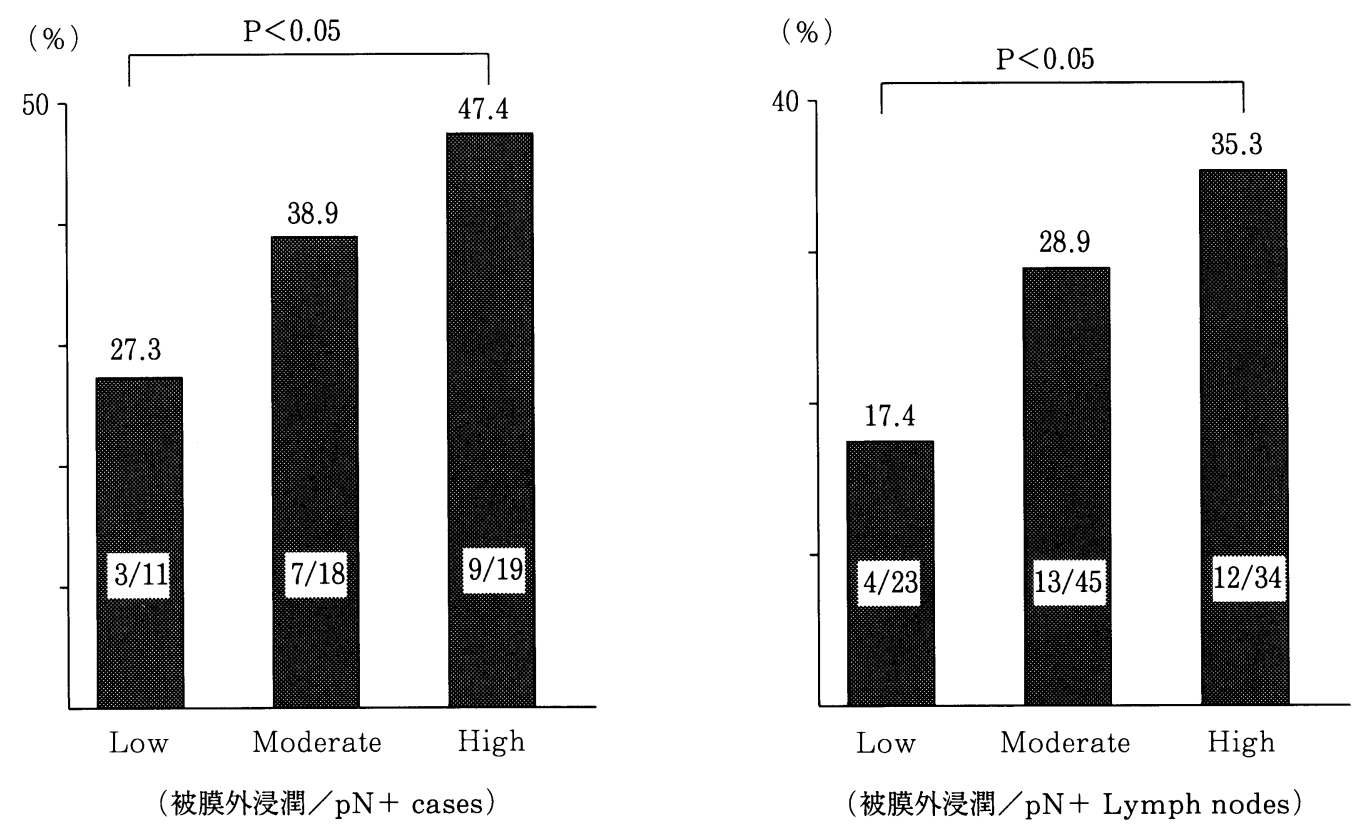

図 4 被膜外浸潤と組織学的悪性度との関連性

表 2 原発巣の浸潤様式と領域リンパ節転移

\begin{tabular}{|c|c|c|}
\hline 浸潤様式 & リンパ節転移 & 被膜外浸潤 \\
\hline 1 & $0(0 / 9)$ & $0(0 / 0)$ \\
\hline 2 & $5.7(3 / 53)$ & $33.3(1 / 3)$ \\
\hline 3 & $19.0(27 / 142) \pi_{*}^{*}$ & $29.6(8 / 27) \square *$ \\
\hline $4 \mathrm{C}, \mathrm{D}$ & $35.7(18 / 51) *{ }^{*}$ & $55.6(10 / 18)-]^{*}$ \\
\hline 計 & $18.8(48 / 255)$ & $39.6(19 / 48)$ \\
\hline
\end{tabular}

また, 原発巣の浸潤様式と被膜外浸潤様式をみると, 明ら かな有意差は認められなかったが, 浸潤様式の 2 型, 3 型 では Tocker 分類の pattern A（被膜外浸潤する前にリン パ節内でかなりの範囲に増殖しているもの) が多く，4C 型, $4 \mathrm{D}$ 型では Tocker 分類の pattern C (リンパ節内外に 同時に浸潤, 増殖するもの), pattern D (早期より被膜外 に浸潤, 増殖するもの）が多くなる傾向が認められた（表 3 ).

\section{考察}

リンパ節転移は癌細胞の性状のみならず, 原発臓器の要 因,さらには宿主反応などが複雑に関与し，それらの相互 作用の結果として発現すると考えられている13,14). しかし
表 3 原発巣の浸潤様式と被膜外浸潤様式

\begin{tabular}{|c|c|c|c|c|}
\hline $\mathrm{Y.K}$ Tocker & A & B & $\mathrm{C}$ & D \\
\hline 2 & 1 & & & \\
\hline 3 & 10 & 2 & 1 & \\
\hline $4 \mathrm{C}, \mathrm{D}$ & & 3 & 8 & 4 \\
\hline
\end{tabular}

ながら, 癌の転移は複雑な生物学的過程を経て惹起され， 癌細胞の浸潤, 増殖と転移形成との関連性や, 転移の機序 が十分に解明されていないのが現状である ${ }^{6,15 \sim 22) . ~ し た ~}$ がって, 癌細胞の生物学的特性を把握し, 癌転移の発生過 程に関与する宿主と腫瘍との関連性を明らかにすることは, 癌細胞の浸潤, 増殖や転移機構の解明に貢献するのみなら ず, 病巣の手術範囲の決定や抗癌剤の選択基準を明確にし， 治療成績の向上に寄与するものと考えられる.

\section{1. 被膜外浸潤の臨床像}

口腔癌における被膜外頸部リンパ節転移の頻度は $37.1 \%$ から $56.0 \%$ と報告されている ${ }^{18,23)}$. 本検討例では転移リン パ節の $28.4 \%$ に被膜外浸潤が認められ, 若干低い転移度を 示していた。また, 原発部位別では, 舌癌で比較的多いとす る報告 $8,18,24)$ がみられるが, 本検討例では上・下顎歯肉癌 に多く, 舌癌は低くなっていた.これは, 下顎歯肉癌では顎 
骨内浸潤や進行例が比較的多かったこと，また上顎歯肉癌 では一次治療として放射線療法を選択していたため，積極 的な予防的頸部郭清手術が行われず, 転移を確認してから ただちに頸部郭清手術を実施したことから, 被膜外浸潤が 多かったものと思われる。一方，一次治療に術前化学療法 と手術を選択していた舌癌では，皮弁による即時再建を実 施しており，便宜的な頸部郭清手術が行われたため，低い 被膜外浸潤頻度となったものと考えられる。

原発巣の大きさと被膜外頸部リンパ節転移との関連につ いて, 原発巣の大きな症例ほどリンパ節転移が多く, 被膜 外浸潤も増加するとされている ${ }^{18)}$. 野口ら ${ }^{8)}$ は T 4 症例で の節外型転移例が多くみられたことについて, 節外リンパ 節の形成には癌細胞が頸部リンパ節に着床し転移を形成し てから臨床的にリンパ節転移が確認されるまでの時間が大 きく関与していると述べている.しかしながら，本検討例 では T 分類による差異は認められず, T $1, \mathrm{~T} 2$ の原発巣非 進展例においても被膜外浸潤が約30～40\%にみられたこと は, 腫瘍の大きさを示す $\mathrm{T}$ 分類のみの評価で被膜外浸潤を 推測することは困難であり, 腫瘍宿主境界線における腫瘍 の浸潤様式, 原発巣の組織学的な性状, 悪性度さらには 転移巣での腫瘍の発育進展様式などとの関与が示唆され る $^{8,24)}$.

頸部リンパ節の転移部位は, レベル 1 に相当する顎下 部に多いとされ ${ }^{8}$ 18), 顎下リンパ節群や内頸静脈に沿っ た上内深頸リンパ節群に高い転移率が報告されてい る $^{6,8,13,15 \sim 19)}$. 被膜外浸潤における本検討例でも，野口 ${ }^{8)}$ の報告と同様に, 顎下リンパ節, 上内深頸リンパ節, 中内深 頸リンパ節にみられたが, 大多数がレベル 2 までに留まっ ていた

被膜外浸潤のみられたリンパ節の大きさについて, 最大 径が30 $\mathrm{mm}$ 前後を示すことが多いとされている ${ }^{8,25)}$ が, 本検討例では最大径の平均値が $20.8 \mathrm{~mm}$ と比較的小さな リンパ節に被膜外浸潤が認められた。この結果からすれば, 被膜外浸潤は転移癌細胞がリンパ節を充満した後の最終段 階で生じるだけでなく, 辺縁洞に着床した癌細胞がリンパ 組織をすべて置換せず, 比較的早期より被膜外に浸潤する 可能性 ${ }^{9,18)}$ を示唆するものと思われる.

\section{2 . 被膜外浸潤と原発巣の病理組織像}

原発巣の組織学的悪性度とリンパ節転移度との関連性に ついては,さまざまな分類で検討されているが統一された 見解はみられない17,22, 26 30). 本症例では, 治療前の生検材 料をもとにAnneroth ら ${ }^{11)}$ の分類を基準に, Yamamoto ら 10)の浸潤様式を加え, 組織学的悪性度を総合的に評価し て検討を行った. その結果, 組織学的悪性度の高いものほ どリンパ節転移における被膜外浸潤の割合が高く，とくに
高悪性型では低悪性型および中等度悪性型よりも有意に高 い被膜外浸潤を示していた。この点について，本間6) は細 胞異型度, 分化度, 細胞分裂頻度, 浸潤様式などを加味した 組織学的悪性度は, 癌細胞の原発巣からの遊離やリンパ節 内における増殖など, 転移形成機転に何らかの形で関与し ているものと思われると述べている．また，野口ら ${ }^{8)}$ は口 腔粘膜癌において被膜外浸潤の約 7 割が高悪性度癌であっ たと報告し, 被膜外浸潤の形式には時間的要因ばかりでは なく癌細胞の浸潤能や増殖能を含めた悪性度が関与してい ると考えられたと述べている.

リンパ節内での転移腫瘍の増殖様式について, 転移腫瘍 は輸入管より辺縁洞に着床し,リンパ流に沿って中間洞か ら傍皮質へと進展し, リンパ節全体を置換するとされてい る $^{6 \sim 9)}$. また, 被膜外浸潤はリンパ節構造のすべてが転移 腫瘍に置換された最終段階と考えられている6,23,30). しか しながら, 辺縁洞に着床した転移腫瘍が辺縁洞に沿って増 殖し，リンパ節を充満することなく，比較的早期に被膜 外浸潤を生じる場合も報告されている $\left.{ }^{9}, 18,31\right)$. とくに， Toker $\left.^{9}\right)$ はリンパ節内で広範囲に増殖してから被膜外に浸 潤するものからリンパ節内でほとんど増殖することなく初 期より被膜外に浸潤するものまでを pattern A〜D の 4 型 に分類し, 大部分が pattern A, B であったが，比較的早期 に被膜外に浸潤する pattern C, D もみられたと報告して いる.

本検討例では, pattern A, B が $55.2 \%$ を占めていたが, pattern C, D が44.8\%を示しており，比較的早期より被膜 外浸潤のみられることを認識しておくべきであろう。

原発巣の浸潤様式と転移巣での進展様式について, 山本 $ら^{30)}$ や篠原ら ${ }^{18)}$ は原発巣の浸潤様式の程度に比例して, 転移リンパ節での被膜外浸潤例の占める頻度が増加する傾 向が認められたと報告し, 原発巣での浸潤様式が転移巣で の腫瘍の発育進展状態にも関連していることを示唆する所 見と考えられると述べている。

本検討例では, 原発巣の浸潤様式と被膜外浸潤において, 明らかな相関性は認められなかったが, 浸潤様式の 2 型や 3 型では, リンパ節内でかなりの範囲で増殖してから被膜 外に浸潤する (pattern A) ことが多く，4C 型や $4 \mathrm{D}$ 型で は転移腫瘍がリンパ節内あるいは被膜外を同時に浸潤する （pattern C) かあるいは比較的早期に被膜外に浸潤する (pattern D) 症例が多くなる傾向がみられた。この点につ いて, 山本ら ${ }^{30)}$, 篠原ら ${ }^{18)}$ は浸潤様式の 2 型, 3 型では大 部分が pattern A, B の初期節内型であるのに対し， $4 \mathrm{C}$, $4 \mathrm{D}$ 型は pattern C, D の比較的早期に被膜外へと浸潤す ることを示唆し, とくに $4 \mathrm{D}$ 型ではその傾向が強く, 治療 上注意すべきであると述べている。したがって，被膜外浸 潤の様式は, 一般的には転移腫瘍がリンパ節内を充満し被 
膜外へと浸潤するものと思われるが, このような時間的な 要因ばかりでなく, 腫瘍細胞自体の浸潤, 増殖能も関与し ていることが示唆された。このように, 原発巣の浸潤様式 や数種の組織学的な因子を加味した組織学的悪性度評価を 参考とすることによって, 頸部リンパ節への転移状況や被 膜外浸潤をある程度推測することが可能と思われる.

\section{3 . 被膜外浸潤の予後と対応}

予後については, 頸部リンパ節転移の有無, 転移位置, 転 移個数によって大きく左右されることが多数報告されてい $3^{6 \sim 8,10,13 \sim 25)}$.

本検討例でも 5 年累積生存率では, 転移を認めなかった 症例は $75.6 \%$ でったのに対し，転移を認めた症例では $42.0 \%$ と有意差を認め，とくに被膜外浸潤のみられた症例 は $27.8 \%$ と著しく低下していた。これは被膜外浸潤を認め た症例では, 頸部リンパ節転移の非制御症例や遠隔転移症 例が多かったためと考えられた。このように，頸部リンパ 節転移, とくに被膜外浸潤は手術後の予後を判定するのに 重要な因子であると思われる。したがって, 治療成績を向 上させるためには, 頸部リンパ節での転移腫瘍の早期発見 とともに転移腫瘍の被膜外浸潤を子測することが重要と思 われる.とくに, 本検討例でみられたように, 被膜外浸潤が 顎下リンパ節や上内深頸リンパ節に多く,これらの部位で の早期発見, 早期治療が課題と考えられた。しかしながら， 被膜外浸潤のみられるリンパ節はある程度の大きさになら ないと臨床的特徽に乏しく, 治療前後での触診や画像診断 での判別が困難であり, 今後のより正確な画像診断の確立 が望まれる。

一方, 手術前の生検において組織学的悪性度の高い症例 や浸潤様式の $4 \mathrm{C}, 4 \mathrm{D}$ 型の症例では被膜外浸潤をきたし やすいことから，このような症例には，予防的郭清術を考 慮する必要があると思われる。また, 被膜外浸潤症例に 対する後療法について, 術後の放射線治療を推奨する報 - 告 $8,26,27)$ がみられるが, その死因として原発巣や頸部の再 発, 遠隔転移など, さまざまであり, 補助化学療法を含めた 後療法が検討されるべきと思われる.

\section{結論}

口腔扁平上皮癌における頸部リンパ節転移の被膜外浸潤 状況と原発巣における各種要因との関連性について検討を 行い, 以下の結果を得た。

1. 全頸部郭清術施行・92例中48例 $(52.2 \%), 102$ リンパ 節 $(8.9 \%)$ に組織学的転移を認めた。そのうち 19 例 (39.6\%), 29リンパ節 $(28.4 \%)$ が被膜外浸潤例であった。

2 . 原発部位では上下顎歯肉癌の転移頻度が高かった。
3. 被膜外浸潤を認めたリンパ節は，上内深頸リンパ節 （レベル 2 ）に集中していた.

4. 被膜外浸潤を認めたリンパ節の大きさの平均值は短

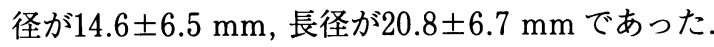

5 . 原発巣の浸潤様式, 組織学的悪性度と被膜外浸潤に 関連性が認められた。

6 . 浸潤様式の $4 \mathrm{C}, 4 \mathrm{D}$ 型や組織学的に高悪性の症例で は予防的郭清手術, 手術後の化学療法や放射線治療の必要 性が示唆された。

\section{引用文 献}

1）桐田忠昭, 岡部貞夫, 他 : 頭頸部扁平上皮癌の後発 転移に関する検討. 日口外誌 39: 1320-1329 1993.

2）宮川 明, 平塚博義, 他 : 口腔癌の潜在性頸部リン パ節転移に関する臨床的, 病理組織学的研究. 札幌 医誌 62: 43-53 1993.

3）黑川英雄, 村田朋之, 他 : 口腔扁平上皮癌の頸部後 発リンパ節転移に関する臨床病理組織学的検討。日 口外誌 43: 661-666 1997.

4）黒川英雄, 村田朋之, 他 : 口腔扁平上皮癌における 頸部リンパ節転移の臨床病理組織学的検討. 口科誌 47: 9 -15 1998.

5) Hermanek, P. and Sobin, L.H.: TNM classification of malignant tumours. 4 th ed, Berlin Splinger-Verlag, 1987, p136-138.

6) 本間義郎：口腔癌の頸部リンパ節転移に関する研究. 日口外誌 28: 1667-1684 1982.

7）立花忠夫：口腔扁平上皮癌のリンパ節転移に関する 臨床的ならびに病理組織学的研究. 口病誌 52: 3193421985

8）野口 誠, 小浜源郁, 他 : 口腔粘膜癌における節外 型頸部リンパ節転移例の検討. 口腔腫瘍 6: 66-73 1994.

9) Toker, C.: Some observation on the deposition of metastatic carcinoma with in cervical ly mph nodes. Cancer 16: 364-374 1963.

10) Yamamoto, E., Kohama, G., et al.: Mode of invasion, bleomycin sensitiovity, and clinical course in squamous cell carcinoma of the oral cavity. Cancer 51: 2175-2180 1983.

11) Anneroth, G., Batsakis, J., et al.: Review of the literature and a recommended system of malignancy grading in oral squamous cell carcinomas. Scand J Dent Res 95: 229-249 1987.

12) Kaplan, E.L. and Meier, P.: Nonparametric estimation from incomplete observations. J Am Stat Ass 53: 457-481 1958.

13）宮川 明, 小浜源郁, 他：口腔癌の頸部リンパ節転 移に関する臨床病理学的検討一特に腫瘍の浸潤様式 との関連についてー. 日口外誌 29: 1555-1561 1983.

14）山本悦秀, 宮川 明, 他 : 口腔粘膜癌切除後の後発 転移に関する検討. 癌の臨床 35: 815-824 1989.

15）矢島幹人, 峯村俊一, 他：口腔扁平上皮癌における 頸部郭清術施行例の臨床統計的検討. 日口外誌 35 : 
647-654 1989.

16）芝良祐, 迫田隅男, 他：口腔領域扁平上皮癌にお ける頸部リンパ節転移の様態と予後. 日口外誌 36 : 1915-1921 1990.

17）堀越 勝, 草間幹夫, 他: 口腔扁平上皮癌の再発性 頸部転移巣の臨床的および病理組織学的検討. 口腔 腫佰 2: 157-162 1990.

18）篠原正徳, 嶋田 誠, 他：口腔癌の頸部リンパ節転 移に関する臨床的・病理組織学的検討. 口腔腫瘍 2 : 113-118 1990.

19）西村泰一, 吉田裕一, 他：口腔扁平上皮癌における 頸部郭清例の検討. 日口外誌 37: 1810-1818 1991.

20）梅田正博, 大森昭輝, 他: 口腔扁平上皮癌の頸部後 発転移に関する臨床病理学的検討. 日口外誌 37 : 143-151 1991.

21）楠川仁吾, 金 賢哲, 他 : 口腔扁平上皮癌 Stage I, II の頸部リンパ節転移に関する臨床病理学的検討. 日口外誌 38: 1292-1298 1992.

22) Kim, H.C., Kusukawa, J., et al.: Clinicopathologic parameters in predicting cervical nodal metastasis in early squamous cell carcinoma of the oral cavity. J Kurume Med 40: 183-192 1993.

23）佐藤 徹, 成瀬裕久, 他: 口腔領域扁平上皮癌の所 属リンパ節転移に関する臨床的, 病理組織学的研究. 日口外誌 42: 662-671 1996.

24) Okamoto, M., Ozeki, S., et al.: Cervical lymph node metastasis in carcinoma of the tongue. $\mathrm{J}$
Cranio-Max-Fac Surg 16: 31-34 1988

25) Snow, G.B., Annyas, A.A., et al.: Prognostic favtors of neck node metastasis. Clin Otolaryngol 7: 185-192 1982.

26) Balteling, H., Breur, K., et al.: The value of post operative radiotherapy as an adjuvant to radical neck dissection. Cancer 52: 1008-1013 1983.

27) Huang, D., Johnson, C.R., et al.: Postoperative radiotherapy in head and neck carcinoma with extracapsular lymph node extention and/or positive resection margins: a comparative study. Int J Radiat Oncol Biol Phys 23: 737-742 1992.

28）東みゆき,藤林孝司，他：上顎癌における頸部リン パ節転移症例の臨床病理学的検討. 日口外誌 36 : 2518-2526 1990 .

29）黒川英雄, 山下善弘, 他 : 口腔扁平上皮癌の組織学 的悪性度についての検討一予後との関連について一. 日口外誌 42: 1-7 1996.

30）山本悦秀, 宮川 明, 他 : 口腔粘膜癌の所属リンパ 節内浸潤増殖像に関する研究一特に原発巣の腫湯の 浸潤様式との関連について. 日口外誌 30: 200-209 1984.

31）新垣 晋 : 口腔領域覀性腫場の頸部リンパ節転移に 関する臨床病理学的研究. 日口外誌 25: 784-797 1979. 